\title{
SAMINISME DAN ISLAM JAWA
}

\author{
Huzer Apriansyah \\ Komunitas Konservasi Indonesia - Warsi \\ Jalan Inu Kertapati No 12 Telanai Pura, Jambi \\ E-mail: huzer.apri@gmail.com \\ HP. +6274166678
}

Abstract: Saminism as cultural identity and part of Indonesian plurality still survives until today. Historically, Saminism was born as a cultural and political reaction against colonialism but practically it was more about religious way, in this point some religions in Java have been interacted with saminism leaders and followers. Based on those facts it would be interesting to understand how the relation between Islamic values and saminism through socio-ethnography. On the other hand, how the history of saminism related to political and social condition of Indonesia is also interesting. Agama Adam or religion of Adam as a way on Saminisme is one of evidence that Islamic values connected with saminism.

Abstrak: Saminisme sebagai identitas budaya dan bagian dari pluralitas Indonesia masih bertahan hingga saat ini. Secara historis, Saminisme lahir sebagai reaksi budaya dan politik melawan kolonialisme. Akan tetapi, secara praktis Saminisme berkaitan dengan aliran agama, dalam hal ini beberapa agama di Jawa telah berinteraksi dengan para pemimpin dan pengikut Samin isme. Berdasarkan fakta-fakta tersebut akan menarik untuk memahami bagaimana hubungan antara nilai-nilai Islam dan Saminisme melalui sosio-etnografi. Di sisi lain, menarik pula dikaji sejarah Samin berhubungan dengan kondisi sosial dan politik di Indonesia. Agama Adam sebagai jalan hidup dalam Saminisme adalah salah satu bukti bahwa nilainilai Islam berhubungan dengan Samin.

Kata Kunci: Saminisme, Islam, Sosio-Etnografi, Agama Adam.

\section{A. Pendahuluan}

Indonesia sebagai bangsa yang begitu plural sampai hari ini masih memiliki komunitas dan juga suku marginal yang masih secara kuat meyakini ajaran mereka dan melaksanakannya. Komunitas dan suku marginal itu biasanya memiliki kekhasan budaya dan perilaku, maka akan segera ingat dengan beberapa 
masyarakat adat. Masyarakat adat Kampung Naga di Tasikmalaya, Suku Baduy di beberapa daerah di Banten, Suku Dayak di pedalaman Kalimantan, Orang Rimba (Suku Anak Dalam) di pedalaman Jambi dan Sumatera Selatan, Orang Tengger di Jawa Timur, dan yang juga terkenal adalah komunitas Samin yang tersebar di beberapa daerah di Jawa Tengah dan Jawa Timur.

Komunitas adat tersebut di atas memiliki kekhasan dalam berbagai hal. Koentjaraningrat (1981: 155) menuliskan bahwa dalam batas wilayah sebuah negara nasional seperti Indonesia, antara kelompok-kelompok masyarakat yang satu dengan yang lainnya memiliki perbedaan atau kekhasan. Perbedaan dan kekhasan tersebut biasanya disebabkan karena adat istiadat, bahasa, serta karena keyakinan religi. Secara teoritis, dikenal pula istilah golongan sosial yang muncul karena tiga faktor, sistem norma, rasa identitas sosial, dan keberlanjutan sosial (Koentjaraningrat 1981: 167). Golongan-golongan sosial inilah yang kemudian memberikan pengaruh pada budaya lokal. Koentjaraningrat juga menyebutkan bahwa penggolongan sosial juga dapat terjadi karena persepsi negatif terhadap sebuah kelompok tertentu, dalam konteks ini ia mencontohkan golongan Negro di Amerika Serikat. Kelompok di luar Negro memang mempersepsikan masyarakat yang memiliki ras negroid ini sebagai individu yang keras, anarkis, dan tidak taat at uran. Dari persepsi itulah, terbentuk penggolongan sosial kepada mereka.

Di Indonesia, proses marginalisasi masyarakat tertentu telah berlangsung sejak masa penjajahan hingga masa pemerintahan Orde Baru. Tsing (1998:3048) menguraikan bahwa antara negara sebagai pemegang kekuasaan mulai dari masa kolonial hingga Orde Baru dengan masyarakat lokal yang marginal terdapat kesenjangan yang luar biasa. Masyarakat marginal mendapat persepsi negatif karena perbedaan-perbedaan yang mereka miliki. Terutama pemikiran yang berbeda dari arus utama pemikiran negara. Negara dalam persepsi kebudayaan nasional seringkali mempersepsikan orang-orang marginal sebagai sisasisa dari masyarakat primitif yang memiliki kecenderungan tidak beradab. Oleh karena itu, pemerintah harus mengintervensi proses sosial politik masyarakat tersebut.

Marginalisasi (peminggiran) terhadap kelompok masyarakat tertentu juga terjadi karena faktor sejarah perlawanan politik masyarakat tertentu. Hal ini terjadi dalam masyarakat Samin yang berkembang di Blora, Pati, Bojenegoro dan Rembang. Samin Surosentiko pengembang ajaran Samin merupakan tokoh lokal yang mengembangkan perlawanan tanpa kekerasan dengan memunculkan karakter nggendeng (Sastroatmodjo, 2003: 10-13). Masih menurut Sastroatmodjo (2003: 11), ada tiga unsur dalam masyarakat Samin. Pertama, gerakan 
Samin serupa dengan organisasi proletariat kuno yang menentang sistem feodalisme dan kolonial dengan kekuatan agraris terselubung. Kedua, gerakan Samin memiliki sifat yang utopis, tanpa perlawanan fisik yang mencolok. Ketiga, gerakan Samin melakukan tantangan terhadap pemerintah yang diperlihatkan dengan prinsip diam, tidak bersedia membayar pajak, dan tidak bersedia menyumbangkan tenaga pada pemerintah.

Dalam konteks sosio-antropologis, sebenarnya sangat menarik untuk mencoba mencari relasi mengenai Islam memberi pengaruh dalam ajaran Saminisme dan juga bagaimana Islam sebagai ajaran memengaruhi perilaku pengikut Saminisme. Sebagai entitas besar yang memengaruhi Nusantara sejak pertama kedatangannya di Nusantara, maka hampir bisa dipastikan ada kontak budaya antara Islam dengan pendiri ajaran Saminisme, Samin Surosentiko, ataupun ketika ajaran Samin telah terformulasi secara lebih konkret dan diikuti para pengikutnya. Tentu saja sebagai sebuah budaya, yang artinya bersifat dinamis, Saminisme juga mengalami persentuhan dengan Islam. Kajian ini mencoba untuk mengungkap beberapa hal terkait relasi Saminisme dan Islam. Beberapa hal tersebut adalah bagaimana sejarah/kisah yang berkembang mengenai muasal Saminisme dan bagaimana relasi Islam dan ajaran Saminisme?

\section{B. Sejarah dan Perkembangan Saminisme}

Saminisme pertamakali disebarkan oleh Samin Surosentiko (Sastroatmodjo, 2003: 7). Samin Surosentiko dilahirkan pada tahun 1859 dengan nama Raden Kohar di Desa Ploso Kedhiren Randublatung, Blora. Ayahnya bernama Raden Surowijaya atau yang di kemudian hari dikenal dengan nama Samin Sepuh. Raden Kohar menggunakan nama Samin Surosentiko, menurut Murbandono (dalam Sinar Harapan, 5 Februari 2005) untuk mendekatkan diri dengan rakyat kecil karena nama Samin adalah nama untuk golongan rakyat kecil.

Penyebaran ajaran Saminisme dimulai dari Desa Klopoduwur, Blora. Dari sinilah, Saminisme mendapat simpati dari rakyat kecil dan dalam waktu singkat pengikutnya telah bertambah dengan cepat. Saminisme menurut Mangoensarkoro (Widodo, 2000) merupakan gerakan sosialis waham (utopian socialism), sedangkan Jasper (Widodo, 2000) mendefinisikan Saminisme sebagai "kelainan jiwa" yang disebabkan oleh besarnya perubahan sosial akibat adanya politik etis. Tjipto Mangoenkosemo menyimpulkan bahwa Saminisme adalah hasil perpaduan antara ajaran Hindu dan perilaku anarkhis petani kuno yang mengekspresikan diri karena penjajahan Belanda dan eksploitasi Kapitalisme. Seorang ahli Belanda Petrus Blumberger menyimpulkan bahwa Saminisme 
adalah ajaran yang didasarkan pada persamaan untuk semua manusia dan pemilikan bersama atas semua tanah dan hasilnya. Dia juga melakukan penolakan terhadap kekuasaan dalam bentuk apapun atau kewajiban-kewajiban sosial lainnya yang berbentuk keharusan membayar pajak dan kerja tanpa upah.

Pada tahun 1907, tepatnya pada tanggal 8 November, Samin Surosentiko diberi gelar Prabu Panembahan Suryangalam (Raja yang menyinari alam). Pemberian gelar ini menurut Morbandono dapat digunakan untuk melihat bahwa gerakan Saminisme juga memiliki kesamaan dengan beberapa gerakan perlawanan rakyat lainnya di Pulau Jawa, yaitu merupakan gerakan mesianis atau gerakan Ratu Adil. Selanjutnya, Soerjanto Sastroatmodjo (2003: 11) menyebutkan ada tiga unsur dalam gerakan Saminisme. Pertama, gerakan Saminisme ini merupakan gerakan yang mirip dengan organisasi proletariat kuno yang menentang sistem feodalisme dan kolonialisme dengan kekuat an agraris terselubung. Kedua, aktivitas dari Saminisme merupakan aktivitas berkelanjutan, gerakan ini bersifat utopis tanpa perlawanan fisik yang mencolok. Ketiga, tantangan terhadap pemerintah yang ditampakkan oleh Saminisme adalah dengan prinsip "diam", tidak bersedia membayar pajak dan tidak bersedia menyumbangkan tenaga untuk negara.

Dari buku berjudul Kearifan Lokal di Lingkungan Masyarakat Samin Kabupaten Blora Jawa Tengah yang ditulis oleh Titi Mumfangati dan kawankawan (2004) merumuskan lima ajaran pokok Saminisme. Pertama, agama adalah senjata atau pegangan hidup. Kedua, jangan mengganggu orang, jangan bertengkar, jangan irihati, dan jangan mengambil hak milik orang lain. Ketiga, Bersikap sabar dan jangan sombong. Keempat, manusia harus memahami kehidupannya sebab hidup hanya satu dan akan dibawa abadi selamanya. Kelima, bila berbicara harus bisa menjaga mulut, jujur, dan saling menghormati. Buku ini tampaknya berupaya menghindari realitas sosial dan politik yang mengitari keberadaan Saminisme, dan cenderung membahas hal-hal yang sifatnya normatif.

Ada kata-kata yang sangat terkenal yang diucapkan oleh Samin Surosentiko ketika berceramah di tanah lapang di Desa Bapangan Blora. Ia mengatakan bahwa tanah Jawa bukan milik Belanda, melainkan milik wong Jowo, maka tidak perlu membayar pajak, justru sang pemiliklah yang harus memanfaatkannya (Murbandono, Sinar Harapan 5 Februari 2005). Ajaran-ajaran perlawanan terhadap kekuasaan yang menindas dan tidak adil secara detail ditulis Samin Surosentiko dalam sebuah kitab Serat Jamus Kalimasada. Menurut Sastroatmodjo (2003: 12) serat ini jatuh ke tangan pejabat Belanda dan dimusnahkan hingga sulit untuk melacak ajaran perlawanan Saminisme, 
namun sebagian masih dapat ditelusuri dari tembang macapatan dan juga dari salinan serat tersebut yang masih disimpan penduduk.

Dalam konteks politik, pengaruh ajaran Saminisme telah mampu menggerakkan perlawanan non violence (tanpa kekerasan) yang dilakukan oleh pengikut Samin terhadap pemerintah Belanda. Pembangkangan-pembangkangan terhadap negara dilakukan oleh pengikut Samin di Blora, Bojonegoro, Pati, Rembang, dan Grobogan serta beberapa daerah lainnya. Adapun penganjur ajaran Samin, Ki Samin Surosentiko, meninggal dunia di pembuangannya di Sawahlunto Sumatera Barat pada tahun 1914. Menurut Murbandono, orangorang Samin sampai saat ini masih mendapat hinaan dari orang di luar pengikut Samin. Begitupun dengan kehidupan berpolitik masyarakat Samin cenderung masih dimarginalkan.

\section{Spiritual Saminisme}

Menurut Hutomo (1996: 22), ajaran spiritual Samin Suronsentiko adalah mengenai manunggaling kawula gusti atau sangkan paraning dumadi. Sangkan paraning dumadi diintepretasikan oleh Parsudi Suparlan dalam kata pengantar pada buku Santri, Abangan dan Priyayi karya Clifford Geertz: Ada ajaran mengenai manusia berasal, apa dan siapa dia pada masa kini, dan kemana tujuan hidup yang dijalani dan dituju. Keyakinan spiritual Saminisme menurut King (1973: 459) seperti dikutip Hutomo (1996: 22) disebut sebagai Agama Adam at au The Religion of Adam. Keyakinan mengenai manunggaling kawula gusti diibaratkan rangka umanjing curiga (tempat keris yang meresap masuk ke dalam kerisnya). Hal ini terdapat dalam serat uri-uri pambudi:

"Rangka umanjing curiga punika ngibarating ngilmu anedahaken pamoring kawula gusti ingkang sejati. Sinaning kawula, jumeneng Gusti balaka. Ageng (gonja) wesi aji punika senepa pamor netepaken bilih kados makaten punika dipun wastani pamoring kawula Gusti, Sejatosipun gesang punika namung kaling-kalingan wuwujudan kita piyambak. Inggih gesang penjenengan inggih ingkang anggesangaken badan kita punika nunggil pancer. Gesang sejati punika inggih gesangi sagung dumados".

(Tempat keris yang meresap masuk ke dalam kerisnya mengibaratkan ilmu ke Tuhan-an. Hal ini menunjukkan pamor (percampuan) antara mahluk dan Khaliknya yang benar-benar sejati. Bila mahluk musnah, yang ada hanyalah Tuhan. Senjata tajam merupakan ibarat campuran yang menunjukkan bahwa itulah yang disebut campuran mahluk dan khaliknya. Sebenarnya yang dinamakan hidup hanyalah terhalang oleh badan atau tubuh kita sendiri yang terdiri dari darah, daging, dan tulang. Hidup kita ini, yang menghidupinya 
adalah yang menjadi sama-sama pancer kita. Hidup yang sejati itu adalah hidup yang menghidupi segala hal yang ada di semesta alam).

Hubungan antara manusia dan Tuhan juga dijelaskan dalam bagian lain dari serat uri-uri pambudi berikut ini:

“...Janjining manungsa gesang wonten dunya punika dados utusaning Pengeran, sageda amewahi asrining jagad, namung sadarni nglampahi. Dados dhumawahing lalampahan begja tuwin cilaka, bingah tuwin susah, saas tuwin sakit, sadaya wau sampun ngantos angresula sanget. Amergi sampun sagah dene prajanjining manungsa. Gesang wonten ing dunya punika segeda angestotaken angger-anggering Allah, dateng asalipun piyambakpiyambak..."

(Menurut perjanjian, manusia adalah pesuruh Tuhan di dunia untuk menambah keindahan jagat raya. Dalam hubungan ini manusia harus menyadari bahwa mereka hanyalah sekadar melaksanakan perintah. Oleh karena itu, apabila manusia mengalami kebahagiaan dan kecelakaan, sedih, dan gembira, sehat, sakit, semuanya harus diterima tanpa keluhan. Sebab manusia adalah terikat pada perjanjiannya. Yang terpenting adalah manusia hidup di dunia ini harus mematuhi hukum Tuhan, yaitu memahami pada asal usulnya masing-masing).

Menurut Suradi, ajaran spiritual Samin merupakan ajaran yang diambil dari Kiai Samin yang berasal dari perpaduan antara ajaran Islam dan nilai-nilai Budaya Jawa. Berikut petikan wawancara dengan Suradi:

"kalau nilai-nilai yang berasal dari arab diterapkan begitu saja ya tidak cocok, maka Mbah Samin itu memadukan nilai-nilai Islam dari Arab dengan nilainilai dari kebudayaan asli sini".

Bila diperhatikan, ajaran spiritual Samin mengenai konsep manusia sebagai ut usan Tuhan yang ada dalam serat uri-uri pambudi pernyataan Suradi ada benarnya. Konsep manusia sebagai utusan Tuhan di dalam Islam sama dengan konsep khalifah yang bisa kita temukan dalam Q.S.2:30 yang artinya sebagai berikut:

"Ingatlah ketika Tuhanmu berfirman pada para malaikat;

"Sesunguhnya Aku hendak menjadikan seorang khalifah di muka bumi". Mereka menjawab:

"Mengapa Engkau hendak menjadikan khalifah di bumi itu orang yang akan membuat kerusakan padanya dan menumpahkan darah, padahal kami senantiasa bertasbih dengan memuji Engkau dan mensucikan Engkau?"

Tuhan berfirman: "Sesungguhnya Aku mengambil apa yang tidak kamu ketahui". 
Selanjutnya, konsep ini dipadukan dengan sikap nrimo sebagai konsekuensi atas posisi manusia yang merupakan "pesuruh Tuhan" hingga berbagai keadaan yang menimpa manusia harus dapat diterima begitu saja. Hal ini tentu saja memiliki kesamaan dengan konsepsi nrimo ing pandum dalam budaya Jawa.

Spiritualitas ajaran Samin ini menjadi salah satu faktor yang memengaruhi tingkah laku sosial mereka sehari-hari. Dalam tradisi lisan masyarakat, menurut penuturan Mbah Randim, agama iku gaman, adam pangucape, man gaman lanang (agama adam adalah senjata hidup). Spiritualitas Saminisme memang dikenal dengan agama Adam. Satu hal lainnya mengenai spiritualitas Saminisme yang sangat penting adalah kepercayaan mereka bahwa manusia pada dasarnya tidaklah pernah mati, karena yang mati adalah jasadnya tetapi urip adalah abadi. Dalam masyarakat Samin, mati adalah berganti pakaian atau salin sandhangan.

\section{Ajaran Sosial Saminisme}

Saminisme dikenal tidak hanya sebagai gerakan spiritual yang memiliki ajaran kebatinan semata, melainkan juga sebagai gerakan sosial dan politik yang memiliki ajaran khusus dalam bidang sosial dan politik. Dalam bidang sosial, ajaran-ajaran Samin banyak berkaitan dengan tata kehidupan individu dalam berhubungan dengan individu lainnya. Berikut ini ajaran Samin Surosentiko mengenai tata at uran perilaku sosial individu. Dalam masyarakat Samin, hal-hal tersebut dikenal dengan angger-angger pratikel. Berikut ini petikannya:

"Tumandukipun sageda anglenggahi keleresan tuwin mawi lalapah ingkang ajeng, sampun ngantos miyar-miyur.Tekadipun sampun ngantos keguh dening godha rencana, tuwin sageda anglampahi sabar lair batosipun, amati sajroning urip. Tumindak ing kelaian sarwa kuwawi anyanggi sadaya lelampahan ingkang dhumawahing sariranipun. Sanadyan kataman sakit, ngerakaos pagesangnipun, ketaman sok serik serta pengawon-awon saking sanes, sadaya wau sampun ngantos ngeresula serta amales piawon, nanging panggalihipun sageda lestari enget."

(Arah tujuannya agar dapat berbuat baik dengan niat yang sungguh-sungguh, sehingga tidak ragu-ragu lagi. Tekad jangan sampai goyah oleh sembarang godaan, serta harus menjalankan kesabaran lahir dan batin, sehingga bagaikan mati dan hidup. Segala tindak tanduk yang terlahir haruslah dapat menerima segala cobaan yang datang padanya. Walaupun terserang sakit, hidupnya mengalami kesulitan tidak disenangi orang, dijelek-jelekkan orang, semuanya 
harus diterima tanpa gerutuan, apalagi membalas berbuat jahat, melainkan orang harus selalu ingat pada Tuhan).

Individu dalam masyarakat Samin dituntut memiliki kesabaran, keteguhan, dan kesadaran sebagai mahluk Tuhan. Ajaran-ajaran ini hingga saat ini masih dianggap penting oleh masyarakat hingga tetap terus dipertahankan, meski dalam praktiknya mengalami perubahan. Ajaran sosial mengenai Saminisme ini menurut Mbah Randim adalah upaya manusia untuk menjaga keseimbangan antara tiga unsur; manusia, alam dan Tuhan. Hal-hal yang berkaitan dengan tata aturan juga termuat dalam hal-hal yang harus ora dilakoni masyarakat Samin (Soewarno, 1977: 16). Hal itu yakni drengki (dengki), srehi (khianat), dahpen (mencampuri urusan orang lain), ndromos (suka meminta barang orang lain dengan kata-kata manis), kemeren (iri hati), nemu disingkiri, bila menemukan barang dikembalikan karena yang kehilangan pastilah bingung, colong jupuk disiriki (jangan mengambil milik orang lain), dan ucapan niku sing bener (berbicaralah yang benar).

Ajaran-ajaran tersebut merupakan ajaran perilaku yang telah ada sejak Samin Surosentiko, hingga saat ini pengikut Saminisme sangat meyakini bahwa untuk hidup selamat di dunia harus mengikuti ajaran tersebut. Ajaran ini juga diyakini untuk diikuti oleh pengikut Saminisme sebagai bekal untuk salin sandhangan (meninggal). Ajaran mengenai perilaku individu ini juga ada dalam undaran sebagai berikut:

Her run tumurning tumus

Winetu hing praja,

Nalar wikan reh kasudarman,

Hayu rumiyeng badra,

Nukti nuting lagon,

Wirama natyeng kewuh

Sangka-sangganing-rat

(Adapun siat-sifat kebaikan

yang layak diajarkan,

tidak lain mesti diolah oleh

pertimbangan nalar

antaranya kewaspadaan dan

bijaksana dalam berbuat sebagai pelindung,

berusaha menanamkan di setiap tempat.,

hendaknya laksana menata gending,

lagu yang bersuasana 
'mengatasi penghalang hayat'

yakni segala yang kita emban

sebagai tugas selaku

mahluk di jagad besar (Sastroatmodjo, 2003: 36-37)

Ajaran yang menyerupai hal di atas juga dapat ditemukan dalam dokumen ceramah Samin Surosentiko di lapangan Desa Kasiman pada 11 Juli 1901.

Lan lakunira saputat-saputat

Nastyasih kukuluwung,

Lagangan harah

Kadyatmikan cuwul heneng

Pambudi malatkung

Sing dingin, hakarsa

Adyatmika tanpolih.

Dwinya maneges tapi

Hakarep tumiyang

Katinempuh Gendholan

Batin, nagarah-arah

Catur mangeran ayun lweh

Dening tatasnya ngadil

Myang

Peneamangkin, sumarah

Rengkep hatikel patuh

Ceramah Samin tersebut menurut Sastroatmodjo menerangkan mengenai kejatmikaan yang berjumlah lima. Pertama, jatmika dalam kehendak, yang berlandaskan pada usaha pengendalian diri. Kedua, jatmika dalam ibadah suci yang disertai pengabdian kepada sesama makhluk. Ketiga, jatmika dalam mawas diri, menjenguk batin sendiri suatu ketika demi keseimbangan diri dan lingkungan. Keempat, jatmika dalam mengatasi bencana, yang terjadi lantaran cobaan Khalik at as mahluk-Nya. Kelima, Jatmika sebagai pegangan budi sejati. Ajaran mengenai sikap individu dalam menghadapi kondisi lingkungan dan tata cara berhubungan dengan individu lain juga muncul dalam tradisi lisan masyarakat pengikut Saminisme, tradisi itu tampak dalam ucapan keseharian, seperti:

Aja drengki, srei, tukar padu, dahpen kemeren, Aja kutil jumput, bedhog colong

(Janganlah mengganggu orang, jangan suka bertengkar, jangan iri hati, jangan suka mengambil barang milik oang tanpa seizin pemiliknya) 
Sabar lan trokal empun ngantos jrengkei srei empun ngantos riya, sepada empun nganti pek pinek kutil jumput bedhog colong. Napa malih bedhog colong, napa malih milik barang, nemu barang neng dalan mawon kula simpangi.

(Berbuatlah sabar dan trokal, janganlah mengganggu orang, janganlah takabur pada sesama orang, janganlah mengambil barang milik orang tanpa seijin pemiliknya. Apalagi mencuri, menemukan barang tercecer di jalan saja itupun dijauhi).

Di samping ajaran-ajaran tersebut, ada lagi sebuah keyakinan yang dimiliki oleh masyarakat pengikut Saminisme yang berkaitan dengan sifat kebersamaan. Semua orang bagi masyarakat Samin adalah saudara (sedhulur) sehingga masyarakat Samin memanggil orang dengan panggilan lur sedhulur. Seperti dikemukakan oleh Mbah Randim, "urip iku nggolek sedhuluran sing okeh, menyang nduk ngendi yo nggolek sedhulur, rak kabeh iki sedhulur”. Secara umum, ajaran-ajaran mengenai pola laku individu ini telah dipahami lama oleh masyarakat dan bagi pengikut Saminisme hingga hari ini tetaplah diperhatikan. Dalam konteks ajaran sosial dalam Saminisme, tampak ada irisan yang signifikan dengan ajaran Islam.

\section{E. Simpulan}

Saminisme bukanlah sebuah komunitas yang melakukan perlawanan politik maupun fisik terhadap kekuasaan (baca kolonialisme) tapi lebih pada ajaran sikap hidup. Sedari awal kelahirannya Hindu dan Islam memberi peran dalam pembentukan ajaran Saminisme oleh Samin Surosentiko yang memiliki nama asli Raden Kohar. Menilik nama Kohar sendiri telah tersirat pengaruh Islam. Ajaran-ajaran religius dan ajaran sosial Saminisme juga mengarah pada substansi ajaran Islam. Interpretasi atas teks-teks agama yang dilakukan Samin Surosentiko maupun pemimpin penerusnya mengalami penyesuaian dengan realitas sosial dan budaya setempat. Ajaran tentang kesalehan religius dan sosial juga mencerminkan pengaruh Islam yang kuat.

\section{Daftar Pustaka}

Abdullah, Taufik. (Ed.). 1996. Sejarah Lokal di Indonesia. Yogyakarta: Gadjah Mada University Press.

Apriansyah, Huzer. 2005. "Budaya dan Perilaku Politik Masyarakat Saminisme" dalam Skripsi. Purwokerto: Universitas Jenderal Soedirman.

Fauzi, Noer. 1999. Petani dan Penguasa. Yogyakarta: Pustaka Pelajar. 
Herman. 1995. Menuju dalam Perjuangan: Sejarah Perjuangan Kemerdekaan di Kabupaten Blora. Blora: Dewan Harian Cabang Angkatan '45. Kab. Blora.

Hutomo, Suripan Hudi. 1991. Tradisi dari Blora. Surabaya: Mitra Almamater. Kahin, Audrey R. 1990. Pergolakan Daerah Pada Awal Kemerdekaan. Jakarta: Grafiti.

Kartodirdjo, Sardono. 2001. Indonesian Historiography. Yogyakarta: Kanisius. Kavanagh, Dennis. 1982. Kebudayaan Politik. Jakarta: Bina Aksara.

Koentjaraningrat. 1981. Pengantar Ilmu Antropologi. Jakarta: Aksara Baru. 1984. Kebudayaan Jawa. Jakarta: PN. Balai Pustaka.

Kuntowijoyo. 1994 (cet. Ke-2). Radikalisasi Petani. Yogyakarta: Bentang. 1999. Budaya dan Masyarakat. Yogyakarta: Tiara Wacana. 2002. Keraton dan Kompeni. Yogyakarta: Bentang.

Mumfangati, Titi dkk. 2004. Kearifan Lokal di Lingkungan Masyarakat Samin di Blora. Yogyakarta: Jarahnitra.

Nugroho, Heru. 2001. Negara, Pasar dan Keadilan Sosial. Yogyakarta: Pustaka Pelajar.

Sastroatmodjo, Soerjanto. 2003. Masyarakat Samin, Siapakah Mereka? Yogyakarta: Penerbit Narasi.

Scott, James C. 2000. Senjatanya Orang-Orang yang Kalah. Jakarta: Yayasan Obor Indonesia.

Soenarjo, Bambang. 1988. Blora Selayang Pandang. Blora: Pemerintah Kab. Blora.

Spradley, James P. 1997. Metode Etnografi. Yogyakarta: Tiara Wacana.

Tsing, Anna Lowenhaupt. 1998. Di Bawah Bayang-Bayang Ratu Intan: Proses Marginalisasi Pada Masyarakat Terasing. Jakarta: Yayasan Obor Indonesia. 